\title{
A Política Social Brasileira no Século XXI: a prevalência dos programas de transferência de renda
}

Valter Martins

Universidade Federal de Santa Catarina (UFSC)

RESENHA: A Política Social Brasileira no Século XXI: a prevalência dos programas de transferência de renda

SILVA, Maria Ozanira da Silva e; YAZBEK, Maria Carmelita; DI GIOVANNI, Geraldo. A Política Brasileira no Século XXI: a prevalência dos programas de transferência de renda. São Paulo: Cortez, 2004. 225p.

BOOK REVIEW: Brazilian Social Policy in the 21st Century: the Prevalence of Income-transfer Programs

SILVA, Maria Ozanira da Silva e; YAZBEK, Maria Carmelita; DI GIOVANNI, Geraldo. A Política Brasileira no Século XXI: a prevalência dos programas de transferência de renda. São Paulo: Cortez, 2004. 225p. 
Os últimos anos do século 20 e o início do século 21 têm sido marcados por profundas alterações no âmbito das políticas sociais, tanto nos países centrais quanto nos países periféricos. As grandes transformações econômicas e sociais, especialmente com o rearranjo do mercado capitalista, a regionalização dos mercados e a crescente concentração do capital financeiro, vêm ocasionado o aumento da pobreza e da exclusão de vastos contingentes populacionais. Nesse cenário, crescem as demandas por ações estatais voltadas à proteção social dos que se encontram fora do mercado de trabalho ou vivendo sua precarização. É a partir desse contexto que Maria Ozanira da Silva e Silva, Maria Carmelita Yazbek e Geraldo di Giovanni apresentam uma instigante pesquisa sobre os programas de transferência de renda desenvolvidos no Brasil.

Na obra, o tema dos programas de transferência de renda é tratado como parte integrante do sistema de proteção social brasileiro, partindo-se da hipótese de que os sistemas de proteção social são formas institucionais que todas as sociedades humanas desenvolvem para enfrentar as "vicissitudes de ordem biológica ou social que coloquem em risco parte ou a totalidade de seus membros" (p. 15). Por sua vez, esses programas são compreendidos "como aqueles que atribuem uma transferência monetária a indivíduos ou famílias", de forma compensatória, com vistas a romper com o "ciclo vicioso que aprisiona grande parte da população brasileira nas amarras da reprodução da pobreza" (p.19).

As medidas de transferência de renda ganharam centralidade na agenda do Estado brasileiro a partir dos anos 1990, com a introdução do projeto neoliberal, que reorienta o sistema de proteção social, alterando o seu caráter universalista e configurando-o sob a ótica da descentralização, da privatização e da focalização, conforme as diretrizes das agências multilaterais. É no leito dessa conjuntura que os autores buscam estudar, de modo sistemático, o conjunto das experiências brasileiras, resgatando seus pressupostos e fundamentos, com indagações e problematizações que permitem vislumbrar as possibilidades de implementação de uma "política pública de transferência de renda" na realidade brasileira.

No primeiro dos quatro capítulos do livro, os autores localizam os antecedentes desse tipo de programas no Brasil em diferentes conjunturas, situam as discussões e propostas surgidas nos âmbitos internacional e nacional e reconstroem os diferentes momentos do debate intelectual e parlamentar sobre o tema, com destaque para as experiências pioneiras desenvolvidas em vários municípios e estados da federação. Nessa análise, demarcam que os programas de transferência de renda, no Brasil, situam-se "no contexto de hegemonia do projeto neoliberal", distanciando-se de forma crescente da perspectiva universalista inscrita na Carta de 1988.
O segundo capítulo aborda os programas nacionais desenvolvidos na década de 1990 e no início dos anos 2000. Do Benefício de Prestação Continuada (BPC), passando pelo Programa de Erradicação do Trabalho Infantil (PETI), Bolsa Escola, Vale-Gás, Bolsa Alimentação e Cartão Alimentação, os autores chegam ao Programa Fome Zero, surgido no governo de Luiz Inácio Lula da Silva. Ganha centralidade na análise a criação do Programa Bolsa Família, marco da unificação dos programas de transferência de renda, abordado ainda em sua fase inicial.

No terceiro capítulo, os autores apresentam os resultados de uma pesquisa desenvolvida junto a 37 programas de transferência de renda em âmbito municipal e 7 em âmbito estadual. Através de um estudo comparativo, as experiências são analisadas em suas arquiteturas, normas, organização e funcionamento, monitorização e avaliação dos impactos junto ao cotidiano da população-alvo.

Finalizando, no quarto capítulo é apresentada uma análise da dimensão qualificadora dos programas, resgatando-se o conjunto de atributos que permitem evidenciar as principais tendências para a construção de uma Política Nacional de Transferência de Renda para o Brasil. Para os autores, ainda que à primeira vista tais programas pareçam bastante imediatistas, a transferência monetária direta representa, para famílias sem nenhuma renda ou com renda insuficiente, condições progressivas para a superação da pobreza e de sua reprodução. Mas, para isso, torna-se necessário afirmar os programas de transferência de renda como política pública capaz de fortalecer os direitos sociais, ampliar a cidadania e caminhar na superação das marcas meritocráticas, residuais e paternalistas do sistema de proteção social brasileiro. Agrega-se aqui a necessidade de aumentar o repasse de recursos financeiros, humanos, materiais e institucionais para o desenvolvimento satisfatório dos programas, além de associá-los a outras políticas estruturantes, como saúde, educação e trabalho.

A conclusão dos autores indica, por fim, que o "viés liberal" e o "caráter compensatório" dos sistemas de proteção social no Brasil só serão superados mediante a formulação de uma "Política Nacional" capaz de articular programas e recursos, associada à revisão do atual modelo de política econômica, concentrador de renda e fortalecedor das desigualdades sociais.

As reflexões apresentadas na obra, de significativa relevância aos estudos no âmbito da proteção social, especialmente em relação aos programas de transferência de renda, trazem importante contribuição tanto ao Serviço Social quanto às diferentes áreas que atuam na construção e na defesa das políticas sociais públicas no Brasil. 


\section{Valter Martins}

Assistente Social

Mestrando do Programa de Pós-Graduação em Ser-

viço Social - UFSC

Orientadora: Profa. Dra. Ivete Simionatto

UFSC-Centro Sócio-Econômico

Programa de Pós-Graduação em Serviço Social

Campus Universitário Reitor João David Ferreira

Lima

Trindade - Florianópolis - SC

CEP: $88010-970$ 